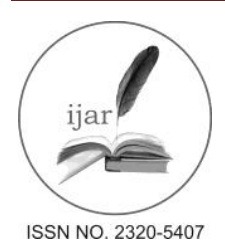

Journal homepage:http://www.journalijar.com

Journal DOI:10.21474/IJAR01

INTERNATIONAL JOURNAL

OF ADVANCED RESEARCH

RESEARCH ARTICLE

\title{
A STUDY ON QUALITY OF WORK LIFE OF WORKERS IN TEXTILE PRODUCTION FIRM.
}

Manish Phuyal (MBA).

Manuscript Info
Manuscript History:
Received: 11 April 2016
Final Accepted: 22 May 2016
Published Online: June 2016
Key words:
Quality of Work Life, Production
Firm, Textile Industry
*Corresponding Author
............................
Manish Phuyal.

\begin{abstract}
An assured good quality of work life is instrumental in attracting talented workforce and also in retaining the existing experienced talent. If quality of life at work could be improved, it would result in all holistic improvement by benefitting the individual worker, the company, its customers and society as a whole. This study was conducted with the aim of analysing the perceived quality of work life of workers, and identifying the areas of improvement in work environment in textile production firms. The study was conducted within a textile production firm with the sample of 51 workers. Quantitative approach of research was opted for studying the problem. Descriptive research design was used and a definite and structured schedule was used as an instrument for collecting primary data using convenience sampling. Simple percentage analysis, frequency analysis, comparison of averages, $t$ test, ANOVA test and correlation test were performed with the help of MS Excel and IBM SPSS software.

The analysis showed that young workforce, and people in the lower end of pay scale at the production firm were unhappy with work environment. Income, age and experience of a worker decided how the worker perceived the work environment. Compensation, autonomy, growth opportunities and training \& development needed improvement. Some improvement measures suggested were: revamping compensation policy, creating autonomous groups for work, providing on the job training, implementing appraisal system that promotes growth, being open to ideas from young workers, and developing a sense of shared vision for inducing commitment.
\end{abstract}

Copy Right, IJAR, 2016,. All rights reserved.

\section{Introduction:-}

India's textiles sector is one of the major pillars of Indian national economy and one of the largest contributing sectors of India's exports contributing 11 per cent to the country's total exports basket. The textiles industry is labour intensive and is one of the largest employers in country.

Quality of work life (QWL) is the extent to which workers of an organization are able to use the experiences in the organization to satisfy their important personal needs. QWL is a multidimensional term which includes nature of the job, work load, job stress, leave benefits, infrastructure, relationship with co-workers and superiors, attitude of the employees, salary, work-life balance and other benefits. It refers to the relationship between employees and their total working environment. It is desirable for both human and performance needs.

\section{Objectives of the Study:-}

* To analyse the satisfaction level of workers in textile production firm with various aspects of their work environment.

* To analyse relationships between various demographic factors (gender, salary, experience, age) of workers with perceived Quality of Work Life. 


\section{Scope and Limitations:-}

* The study is conducted amongst workers of textile manufacturing company named Javi Home Private Limited (Javi), Panipat, Haryana, India.

* The population for study consists of factory workers working at Javi and not the managers and supervisors.

* Convenient sampling has been used in the study and it has its own limitations.

* Results of the study may not be generalized to areas other than textile production.

\section{Literature Review:-}

Many authors, psychologists and management consultants agree that it is difficult to give a clear definition of the term quality of work life, other than that it has to do with the well-being of employees. All accept that different people will have different perspectives on what makes for high quality of work life.

Following table depicts some components of QWL as viewed by scholars in various types of organization.

Table 2.1:- Components of QWL as viewed by scholars.

\begin{tabular}{|l|l|}
\hline Author & Components \\
\hline Walton (1975) & Adequate And Fair Compensation, \\
& Safe And Healthy Working Conditions, \\
& Immediate Opportunity To Use And Develop Human Capacities, Opportunity For \\
& Continued Growth And Security, \\
& Social Integration In The Work Organization, \\
& Constitutionalism In The Work Organization, \\
& Work And Total Life Space, \\
& Social Relevance Of Work Life. \\
\hline Stein (1983) & Autonomy or being independent; \\
& Being recognized and prized; \\
& Belongings; \\
& Progression and development; \\
& External reward \\
\hline Ellis and Pompli (2002) & $\begin{array}{l}\text { Poor working environments, } \\
\text { Resident aggression, }\end{array}$ \\
& Workload, \\
& Unable to deliver quality of care expected, \\
& Balance of work and family, \\
& Shift work, no involvement in decision making, \\
& Professional isolation, non-recognition of work, \\
& Unhealthy relationships with supervisor/peers, Role conflict, \\
& Absence opportunity to learn new skills. \\
\hline GunaSeelan & Health and well-being, \\
Rethinam\&Maimunah & Job security, \\
Ismail & Job satisfaction, \\
(2008) & Competence development \\
& The balance between work non work life \\
\hline Seyed Mehdi & 1. Fair and adequate pay and benefits rights, \\
Hosseini, Gholamreza & 2. Observance of safety and health factors, \\
MehdizadehJorjatki & 3. Opportunities to continue growth and security of staff, \\
(2010) & 4. Acceptance work organization, \\
& 5. Work life and social dependence on society and individual life, \\
& 6. Governing the overall living space in the environment, \\
7. Integration of social improved human abilities \\
\hline
\end{tabular}




\begin{tabular}{|l|l|}
\hline Stephen, A. (2012). & 1. Adequate and fair compensation \\
& 2. Fringe benefits and welfare measures \\
3. Job security & 4. Physical work environment \\
5. Work load and job stress \\
6. Opportunity to use and develop human capacity \\
7. Opportunity for continued growth \\
8. Human relations and social aspect of worklife \\
9. Participation in decision making \\
10. Reward and penalty system \\
11. Equity, justice and grievance handling \\
12. Work and total life space \\
13. Image of organization
\end{tabular}

(Jeyaratham \& Malarvizhi, 2011), in their article discussed about the Quality of work life among Sugar mill Employees in Erode District. The results of the study revealed that the basic strategy for improving quality of work life is to first identify employee's important needs and to satisfy those needs. The study indicated that increase in quality of work life results in increase in productivity and dissatisfaction might occur due to lack of recognition, tedious work, unhealthy peer relation, poor working condition, low self-esteem, occupational stress, heavy work load, monotony, fatigue, time pressures, job insecurity, instability of job etc. The study recommended that promotion policies could be improved by giving grade for designation according to the experience of the employees, and arranging meditation classes and entertainment programmes for employees could minimize occupational stress.

(Shiney, 2012), conducted a study on Quality of Work life and organizational performance at work place of a private manufacturing unit, Nagpur,India through a structured questionnaire containing 31 items related to 6 variables, namely organizational performance, job satisfaction, QWL, wage policy, company policy and union policy. The researcher formulated two models: first, organization performance depends on QWL, Job satisfaction, wage policy, company policy and union participation, and second, QWL depends on Organization performance., job satisfaction, wage policy, company policy and union participation. The collected data were analysed using simple percentage, regression and correlation analysis. The study revealed that both the models stood true and QWL had significant relationship with organizational performance.

(Valarmathi \& Hema, 2013), in their study reckoned the effects of quality of work life in textile sectors in and around Coimbatore district. The factors that were considered were salary, fair compensation, opportunities, job rotation, authority, activities, career prospects, job security, training and health. The study revealed that respondents were not satisfied with salary and compensation. The ANOVA test revealed that there was no significant difference in the mean opinion on job rotation, training and there was a significant difference in opinion for job security and authority to do the work. The correlation test implied a positive correlation between fair compensation and career opportunities.

(Gayathiri \& Ramakrishnan, 2013), in their article, made an attempt to review the literature on quality of life to identify the concept and measurement variables along with linkage to satisfaction and performance. They discussed review of various authors about quality of work life-concept and dimensions of QWL-job satisfaction and performance. Based on the paper, the identification of measures of quality of work life is indeed a difficult task, though there is a sort of common agreement on its concept of employee well-being.

(Rathmani \& Rameshwari, 2013), in their study focused to examine the quality of work life of employees in Textile industry Sipcot, Perundurai. The research findings revealed that motivational insight viz. promotion, insurance protection, training, awards recognition were the influencing factors of quality of work life. Quality of work life influenced job security, good working condition, adequate and fair compensation and monetary rewards. The respondents gavefavourable response on the job satisfaction, safety and healthy working condition, opportunities to develop human capacities and opportunities for continued growth and security of their organization. They also expected higher compensation from their employers.

(Anand, 2013) in his study assessed the quality of work life among employees in Indian Textile industry using Walton's model. The results with regard to fair and adequate payment showed that among employees opinion this 
component was lower than the average and their salary was not satisfactory and was not associated with their job. Thus this cause job dissatisfaction among employees.

\section{Research Methodology:-}

Quantitative approach was followed to conduct the study using descriptive research design. The population universe for this study comprised of all the workers (excluding managers and supervisors) employed by the organization. A sample of 51 workers were surveyed using convenience sampling technique. Respondents were selected based on their willingness to provide relevant information.

Schedule was used as the instrument for data collection because of its suitability (low literacy level amongst workers requiring an enumerator for comprehending the survey questions). The schedule for this study consists of questions which can only be answered objectively. Respondent is supposed to select an option from multiple options. The schedule is structured i.e. it is definite and organized.

The schedule is divided into two sections namely, Demographic and Perception on aspects of work life.

\begin{tabular}{|l|l|}
\hline Demographic section & $\begin{array}{l}\text { Consists of } 4 \text { items of demography of respondent (Gender, } \\
\text { Age, Experience, Income) }\end{array}$ \\
\hline Perception on aspects of work life section & $\begin{array}{l}\text { Consists of } 22 \text { items which can be categorized into 10 } \\
\text { distinct factors/dimensions/aspects of QWL. Each item } \\
\text { measures satisfaction level of the respondent with respect } \\
\text { to that item; which is an indicator of how a worker } \\
\text { perceives that item. }\end{array}$ \\
\hline
\end{tabular}

Simple percentage analysis, frequency analysis, comparison of averages, t-test, ANOVA test and correlation test were performed with the help of MS Excel and IBM SPSS software.

\section{Data Analysis:-}

For the purpose of analysis, rating for each factor (aspect of QWL) was calculated as average weight of items (in data collection schedule) belonging to that factor. Overall satisfaction (perceived QWL) for each respondent was then calculated as an average of all the factor ratings for that respondent. A cut-off score of 3 (neutral point in the scale used) was chosen to determine if a respondent was satisfied or unsatisfied with the work environment. Overall satisfaction above 3 was considered as satisfied and less than or equal to 3 was considered unsatisfied.

\section{Demographic Statistics:-}

Following table shows the frequency and percentage of classifications of respondents:

Table 4.1.1:- Demographic Profile of Respondents

(Source: Primary Data).

\begin{tabular}{|c|c|c|}
\hline Variable & Frequency & Percentage (\%) \\
\hline \multicolumn{3}{|l|}{ Gender } \\
\hline Male & 30 & 58.82 \\
\hline Female & 21 & 41.18 \\
\hline \multicolumn{3}{|l|}{ Age (years) } \\
\hline $18-30$ & 17 & 33.33 \\
\hline $31-45$ & 30 & 58.82 \\
\hline Above 45 & 4 & 07.85 \\
\hline \multicolumn{3}{|l|}{ Experience } \\
\hline Below 1 year & 20 & 39.22 \\
\hline $1-5$ years & 26 & 50.98 \\
\hline $6-10$ years & 5 & 09.80 \\
\hline Above 10 years & 0 & 00.00 \\
\hline \multicolumn{3}{|l|}{ Income (per month) [Rs] } \\
\hline $6,000-8,000$ & 7 & 13.73 \\
\hline $8,001-10,000$ & 33 & 64.70 \\
\hline $10,001-15,000$ & 9 & 17.65 \\
\hline Above 15,000 & 2 & 03.92 \\
\hline
\end{tabular}


Table 4.1.1 highlights that, out of 51 respondents $30(58.82 \%)$ are male and $21(41.18 \%)$ are female. $17(33.33 \%)$ of respondents belong to the age group of $18-30$ years, 30 (58.82\%) belong to age group 31-45 years and 4 (7.85\%) belong to age group above 45 years. It is also clear from the table that $20(39.22 \%)$ respondents have experience of less than 1 year in the organization, $26(50.98 \%)$ have experience of 1-5 years, 5(9.80\%) have experience of 6-10 years and none amongst the respondents has experience above 10 years with the firm. Also, 7 (13.73\%) respondents have income (in INR) ranging from 6,000-8,000, 33 (64.70\%) have income ranging from 8,001 - 10,000, 9 (17.65\%) have income ranging from 10,001-15,000 and 2 (3.92\%) respondents have income above 15,000.

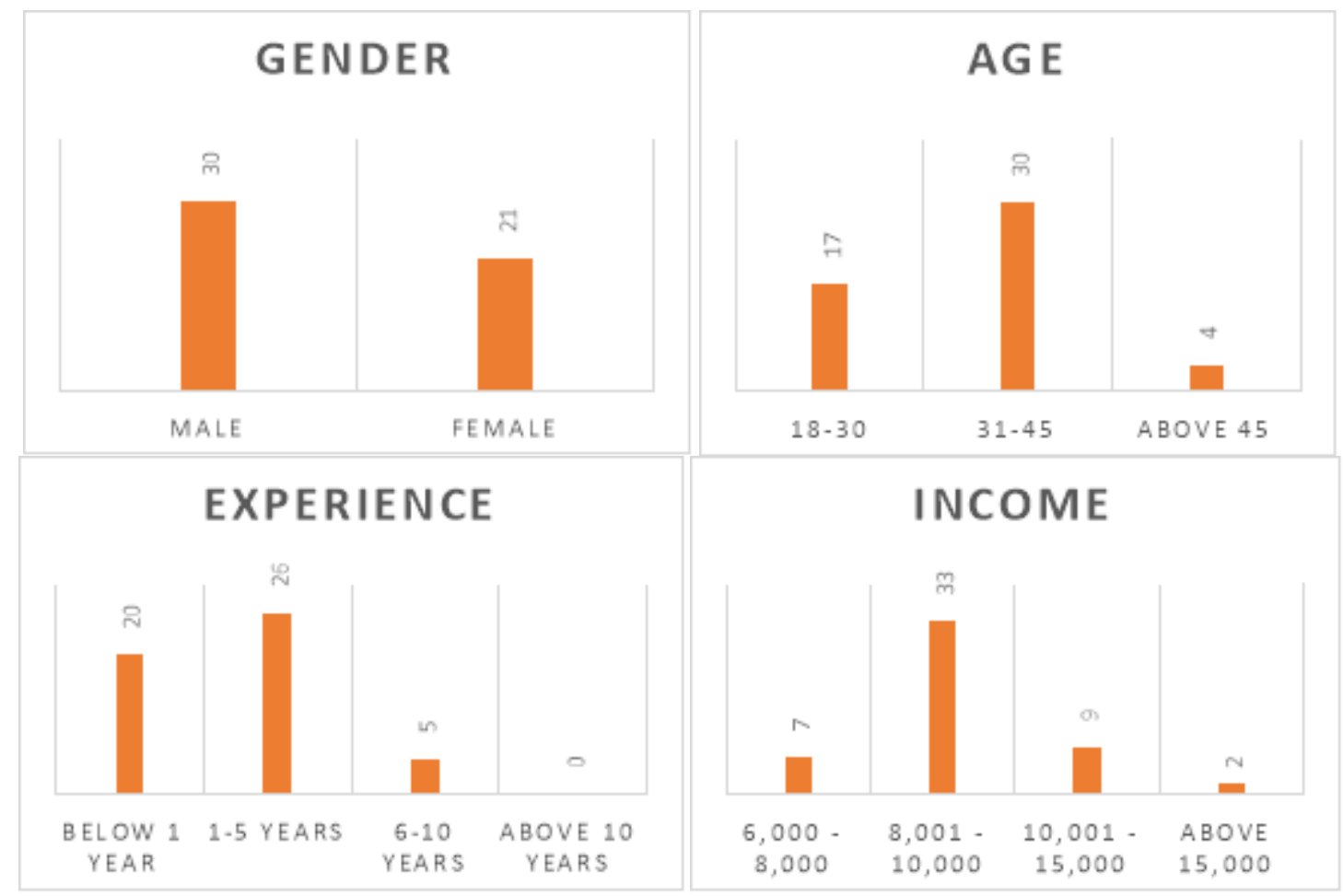

Figure 4.1.1:- Demographic Statistics (Source: Primary Data)

From the statistics we can observe that majority of respondents are male (30/51). Most of the respondents belong to age group of 31-45 (30/51) and experience group of 1-5 years (26/51). 8,001-10,000 is the income category with highest frequency (33/51).

Percentage Analysis:-

Following table shows the comparison of satisfied and unsatisfied respondents.

Table 4.2.1:- Comparison of Satisfied vs Unsatisfied.

(Source: Primary Data)

\begin{tabular}{|l|l|l|l|l|l|l|}
\hline & Total & Total \% & Male & Male \% & Female & Female \% \\
\hline Satisfied & 34 & $67 \%$ & 19 & $63 \%$ & 15 & $71 \%$ \\
\hline Unsatisfied & 17 & $33 \%$ & 11 & $37 \%$ & 6 & $29 \%$ \\
\hline
\end{tabular}




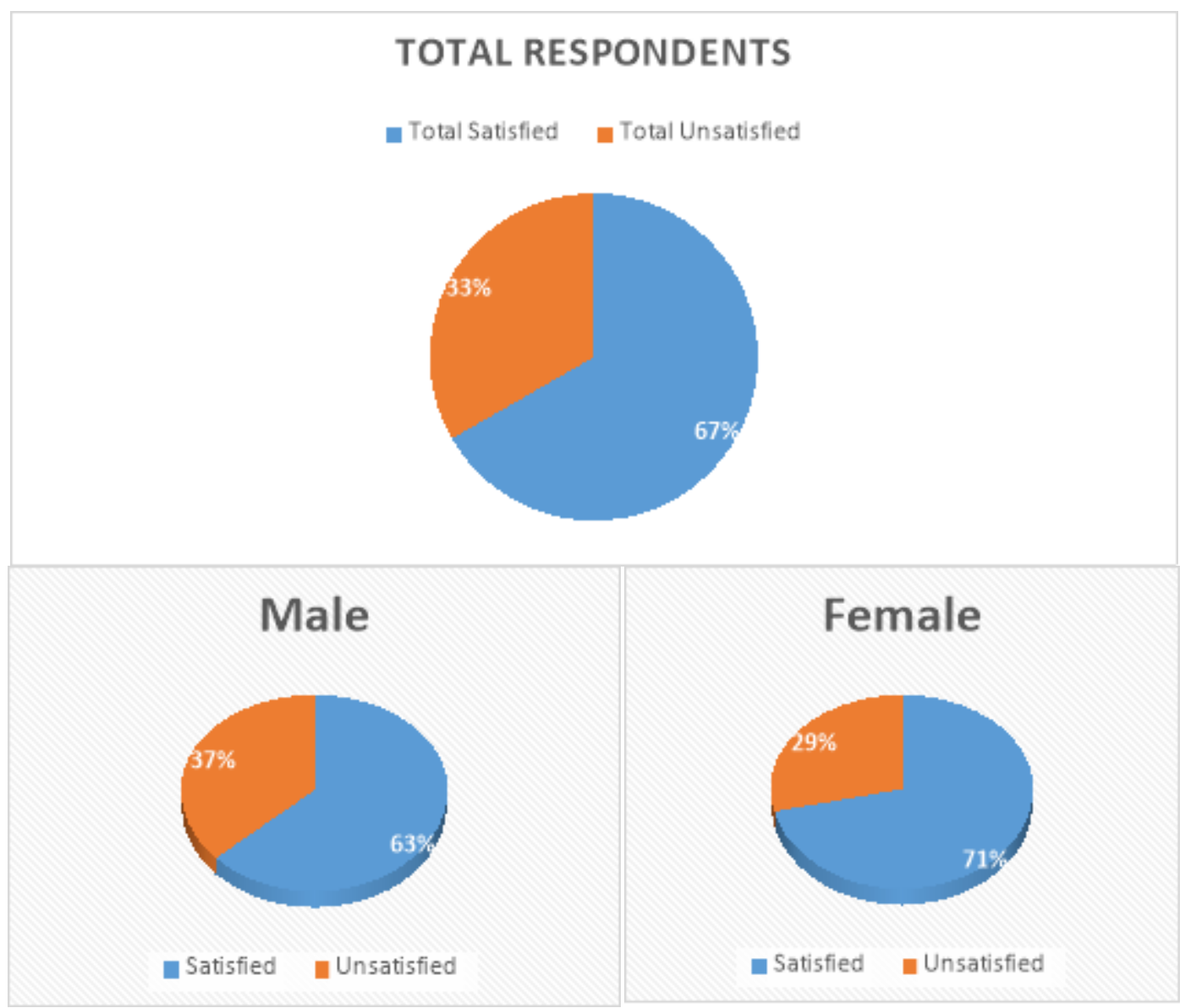

Figure 4.2.1:- Comparison of Satisfied vs Unsatisfied.

(Source: Primary Data)

From table 4.2 .1 it is evident that, $67 \%$ of respondents are satisfied with their work environment and $33 \%$ are unsatisfied. $63 \%$ of male are satisfied with their work environment with $37 \%$ male unsatisfied and $71 \%$ of female are satisfied with their work environment with $29 \%$ female unsatisfied.

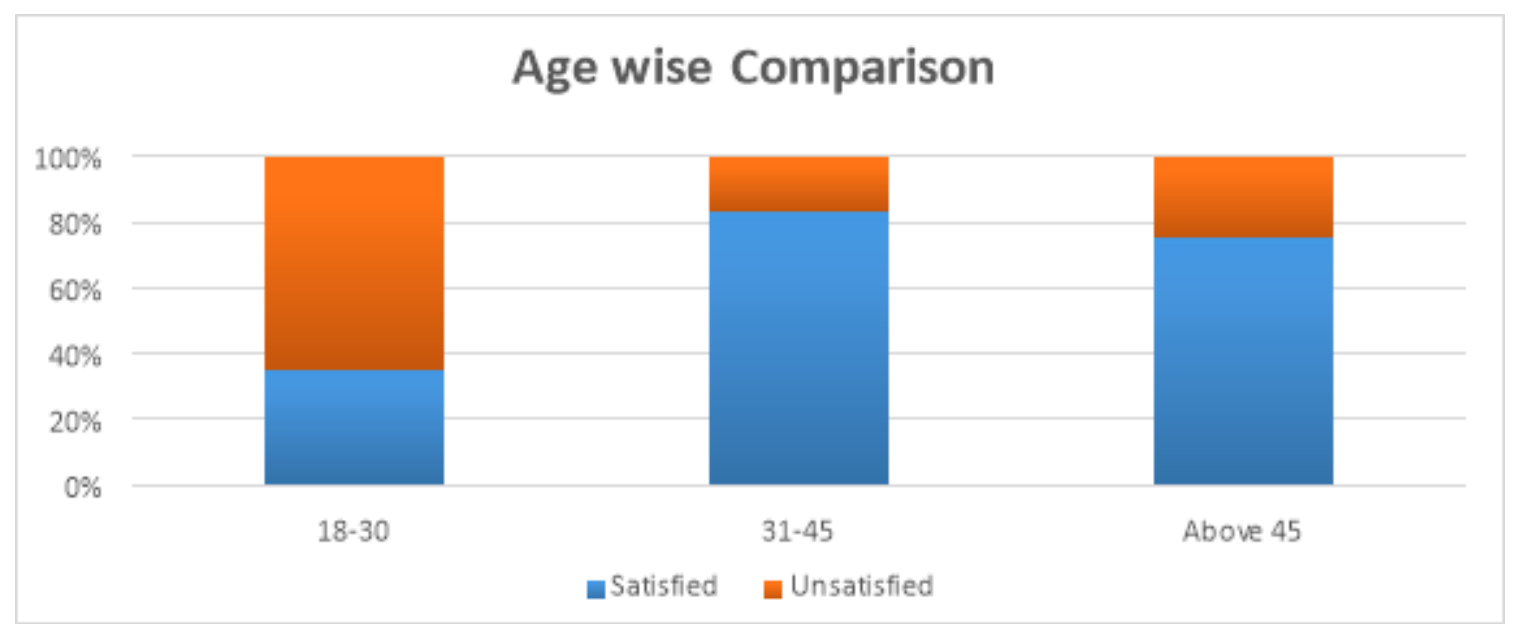

Figure 4.2.2:- Age wise - Satisfied vs Unsatisfied (Source: Primary Data) 
From the analysis of data it is found that, $35.29 \%$ of respondents from age group 18-30 are satisfied with their work environment, whereas, $64.71 \%$ are unsatisfied. $83.33 \%$ of respondents in age group 31-45 are satisfied and $16.67 \%$ are unsatisfied. In age group above $45,75 \%$ of respondents are satisfied and $25 \%$ are unsatisfied.

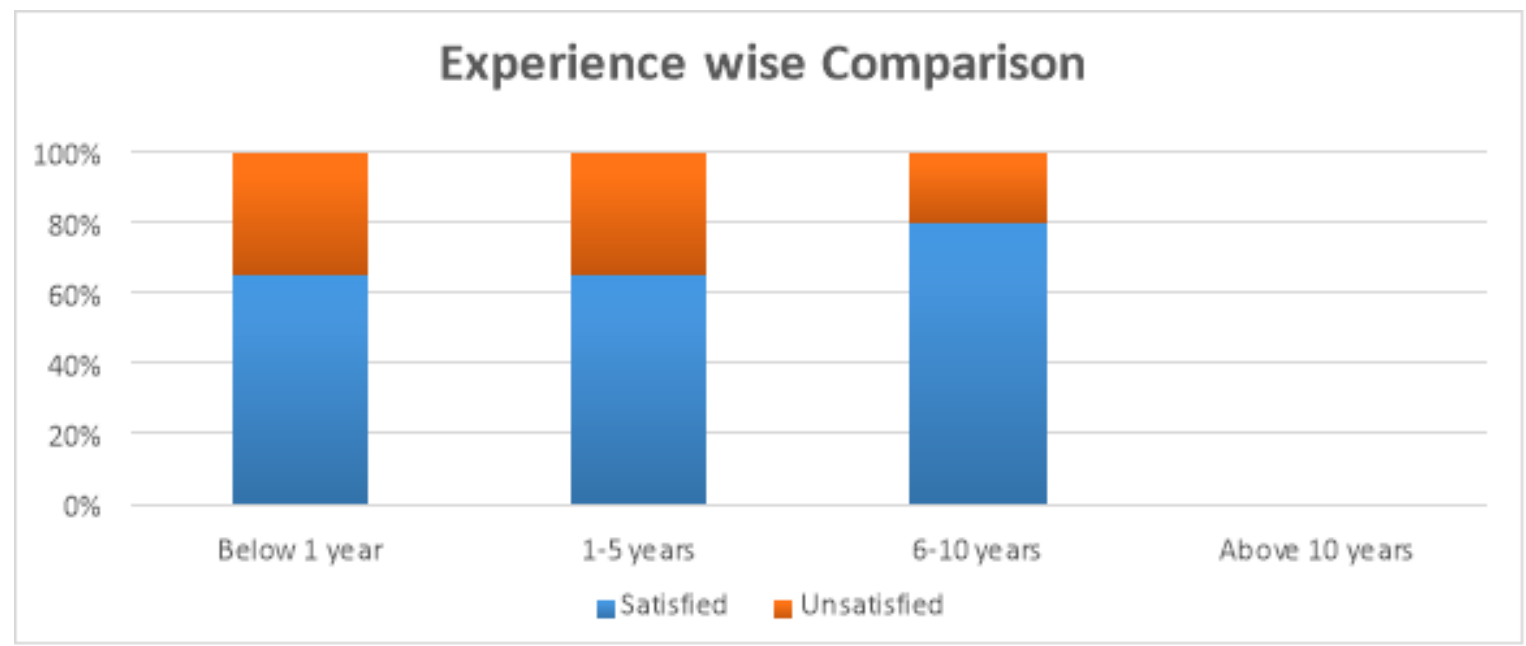

Figure 4.2.3:- Experience wise - Satisfied vs Unsatisfied.

(Source: Primary Data)

The analysis also reveals that $65 \%$ of respondents with less than 1 year of work experience are satisfied and $35 \%$ are unsatisfied with the work environment. In ' $1-5$ years' experience group, $65.38 \%$ of respondents are satisfied and $34.62 \%$ are unsatisfied. $80 \%$ of respondents are satisfied and $20 \%$ are unsatisfied in ' $6-10$ years' experience group.

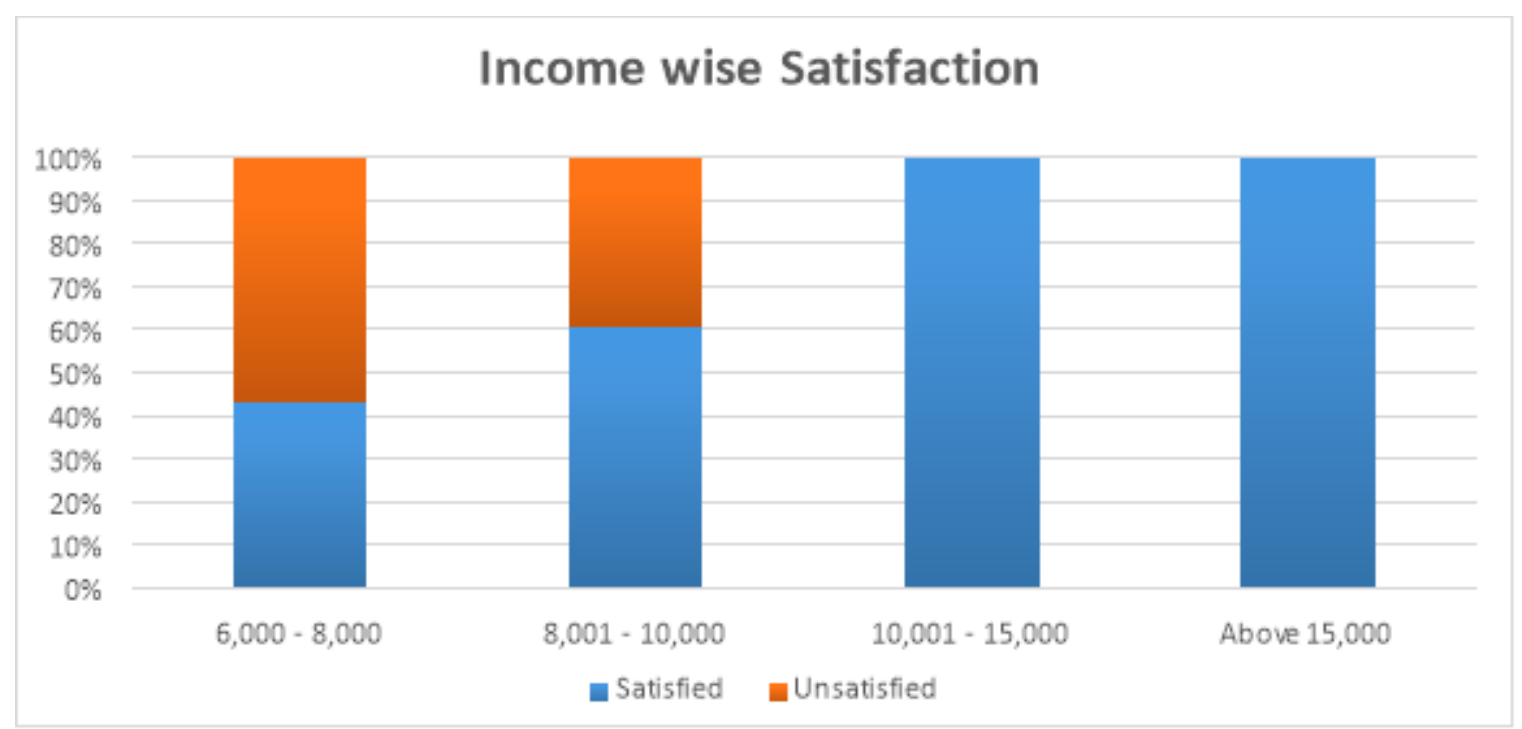

Figure 4.2.4:- Income wise - Satisfied vs Unsatisfied.

(Source: Primary Data)

The analysis of data shows that, amongst respondents earning $6,000-8,000,42.86 \%$ of respondents are satisfied with the work environment and $57.14 \%$ are unsatisfied. Similarly, amongst those earning 8,001-10,000,60.61\% are satisfied and $39.39 \%$ are unsatisfied. $100 \%$ of all the respondents in earning groups 10,001-15,000 and Above 15,000 are satisfied with their work environment. 


\section{Analysis of Averages:-}

\section{Gender wise average satisfaction}

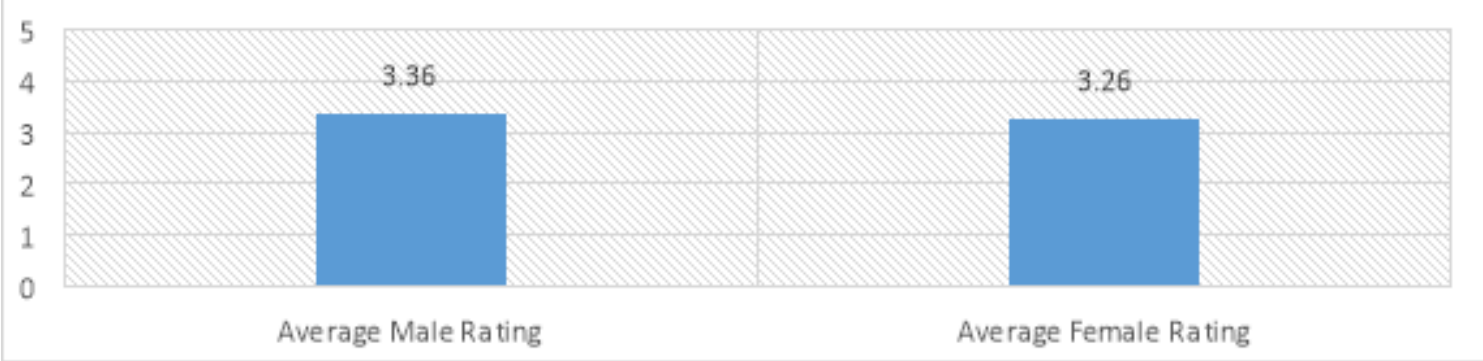

Figure 4.3.1:- Gender wise Average Overall Satisfaction.

(Source: Primary Data)

Figure 4.3.1 shows the gender wise comparison of average rating of overall satisfaction of each gender. It is clear from the figure that average male rating is 3.36 out of 5 and average female rating is 3.26 out of 5 .

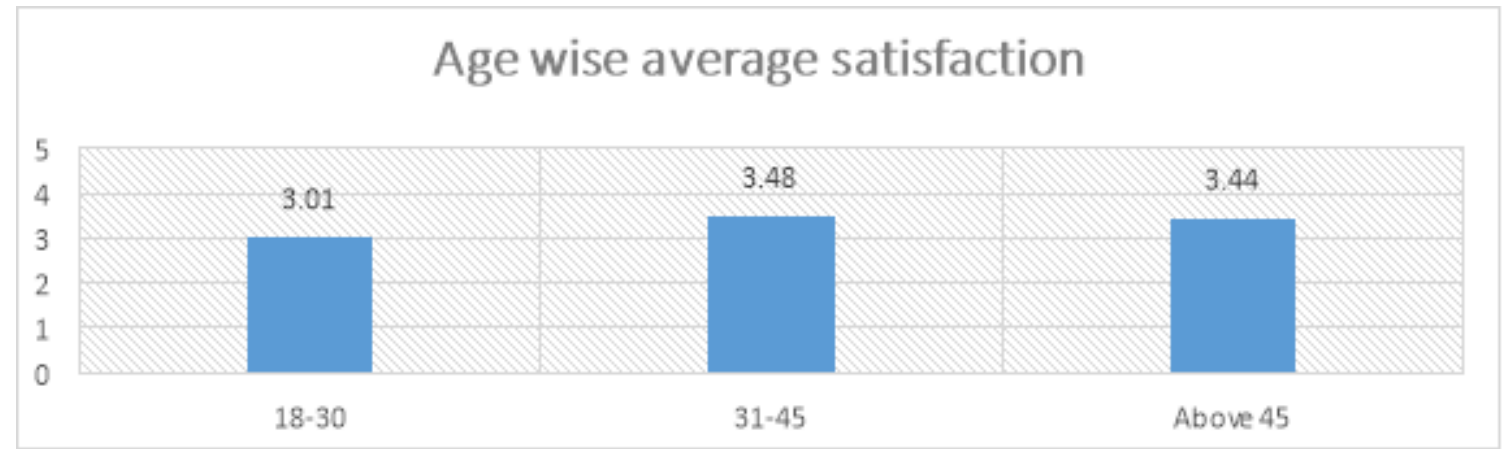

Figure 4.3.2:- Age wise Average Overall Satisfaction.

(Source: Primary Data)

Figure 4.3.2 reveals that average overall satisfaction of people in age group 18-30 years is 3.01 out of 5, in 31-45 years is 3.48 out of 5 and, in Above 45 years is 3.44. Age group 31-45 years has highest average overall satisfaction of the three age groups surveyed.

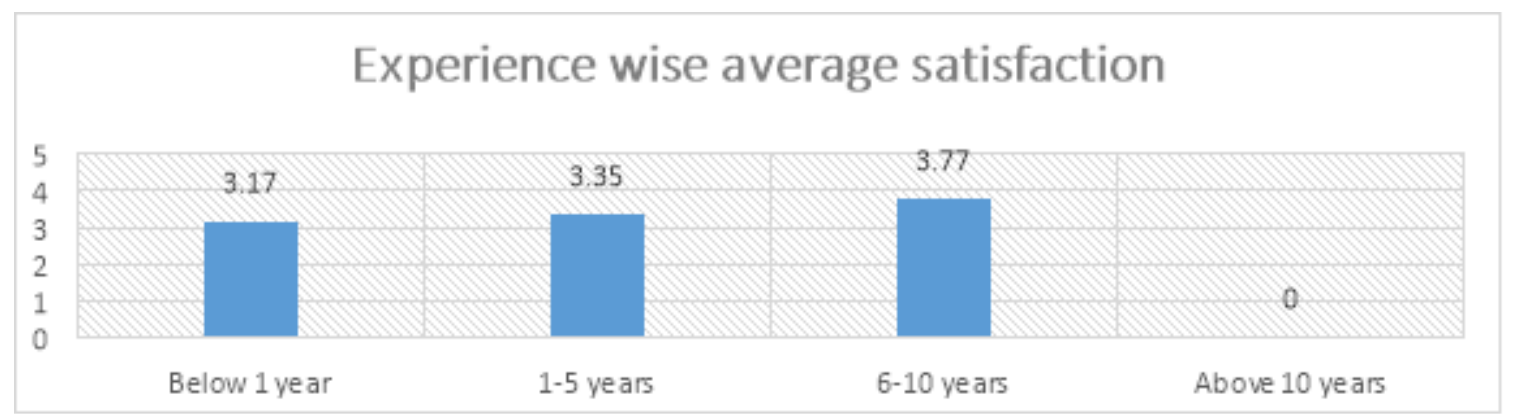

Figure 4.3.3:- Experience wise Average Overall Satisfaction.

(Source: Primary Data)

Based on Figure 4.3.3, workers with experience below 1 year at the firm have average overall satisfaction of 3.17 out of 5. Similarly, workers in experience group 1-5 years and 6-10 years have average overall satisfaction of 3.35 out of 5 and 3.77 out of 5 respectively. 


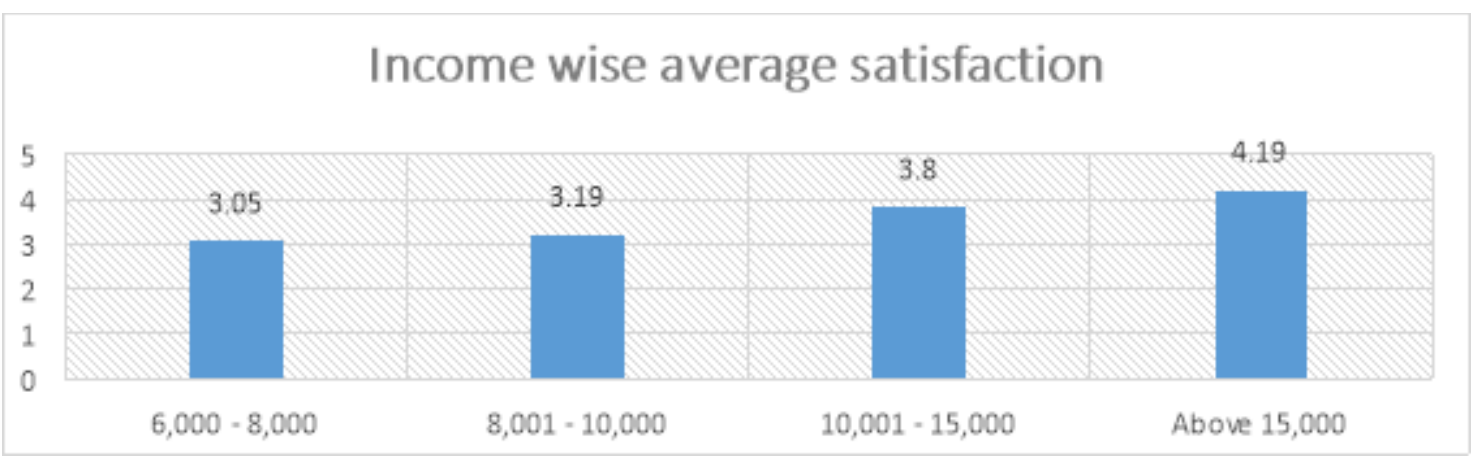

Figure 4.3.4:- Income wise Average Overall Satisfaction.

(Source: Primary Data)

From figure 4.3.4 it is clear that, workers earning in between 6,000-8,000 INR have average overall satisfaction of 3.05 out of 5. Those earning in between 8,001-10,000 INR have average overall satisfaction 3.19. 10,001 - 15,000 INR category have average overall satisfaction of 3.80 and workers earning more than 15,000 have highest average overall rating of 4.19 out of 5 .

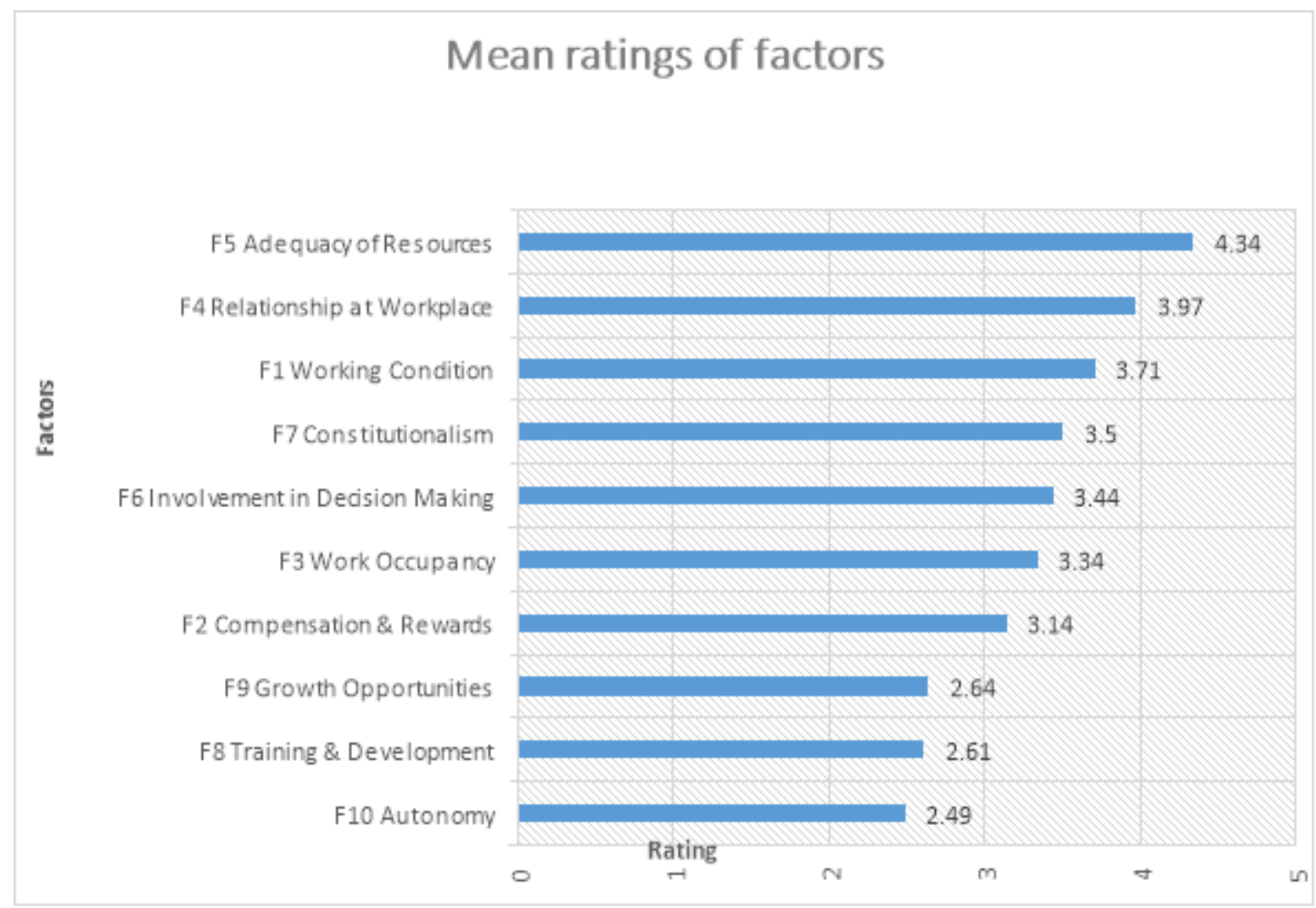

Figure 4.3.5:- Mean Ratings of Factors of QWL.

(Source: Primary Data)

Figure 4.3.5 shows average rating (out of 5) for each factor/dimension of QWL. Working condition has an average rating of 3.71, compensation and rewards 3.14, work occupancy 3.34, relationship at workplace 3.97, adequacy of resources 4.34, involvement in decision making 3.44, constitutionalism 3.50, training and development 2.61, growth opportunities 2.64 and autonomy 2.49. Adequacy of resources, relationship at workplace and working condition are the factors which are have higher ratings. Growth opportunities, Training and development and Autonomy are factors with lower ratings. Adequacy of resources is rated highest and Autonomy is rated lowest by workers. 
Test of Hypotheses:-

Gender vs QWL:-

T-test has been performed to check whether or not the gender is associated with QWL. Following are the hypotheses proposed prior to the test:

$\mathbf{H}_{\mathbf{0}}$ : There is no significant difference between different Gender's perceptions on QWL

$\mathbf{H}_{1}$ : There is a significant difference between different Gender's perceptions on QWL

Levene's test of equality of variances revealed the $\mathrm{F}$ value of 6.867 with significance of 0.012 . Thus, the difference in variances is statistically significant and, therefore, equal variance is not assumed in t-test for equality of means.

Table 4.4.1:- Independent Sample T-test for Gender vs QWL.

(Source: SPSS Output)

\begin{tabular}{|c|c|c|}
\hline & Male & Female \\
\hline $\mathrm{N}$ & 30 & 21 \\
\hline Mean & 3.36 & 3.26 \\
\hline Standard Deviation & 0.53 & 0.34 \\
\hline t-value & \multicolumn{2}{|c|}{0.798} \\
\hline df & \multicolumn{2}{|c|}{0.762} \\
\hline Sig (2 tailed) & \multicolumn{2}{|c|}{0.429} \\
\hline
\end{tabular}

Since the p-value (0.429) is more than the significance level at $0.05(5 \%)$, the difference in means is not statistically significant. Therefore, null hypothesis cannot be rejected. Which means, there is no significant difference between different gender's perceptions on QWL.

Age vs QWL:-

Analysis of Variance (ANOVA) test has been performed to test the associations between age and perceived QWL.

Following hypotheses are proposed prior to test:

$\mathbf{H}_{\mathbf{0}}$ : There is no significant relationship between Age and perceived QWL

$\mathbf{H}_{\mathbf{1}}$ : There is a significant relationship between Age and perceived QWL

Table 4.4.2:- ANOVA test for Age vs QWL.

(Source: SPSS Output)

\begin{tabular}{|c|c|c|c|c|c|}
\hline & Sum of Squares & df & Mean Square & F & Sig. \\
\hline Between Groups & 2.478 & 2 & 1.239 & 7.255 & 0.002 \\
\hline Within Groups & 8.197 & 48 & 0.171 & & \\
\hline Total & 10.674 & 50 & & & \\
\hline
\end{tabular}

Table 4.4.2 shows the p-value of 0.002 which is statistically significant at the significance level of $0.05(5 \%)$. It means, there is only $0.2 \%$ of chance ( 2 out of 1000) that the difference in mean of various age groups is caused by sampling alone. Hence, there is an association between age group and overall satisfaction causing the variation in mean. Therefore, null hypothesis is rejected and the data supports the alternative hypothesis i.e. there is a significant relationship between age and perceived QWL.

\section{Experience vs QWL:-}

Analysis of Variance (ANOVA) test has been performed to test the associations between experience and perceived

QWL. Following hypotheses are proposed prior to test:

$\mathbf{H}_{0}$ : There is no significant relationship between Experience and perceived QWL

$\mathbf{H}_{\mathbf{1}}$ : There is a significant relationship between Experience and perceived QWL

Table 4.4.3:- ANOVA test for Experience vs QWL (Source: SPSS Output)

\begin{tabular}{|l|l|l|l|l|l|}
\hline & Sum of Squares & df & Mean Square & F & Sig. \\
\hline Between Groups & 1.531 & 2 & .765 & 4.018 & .024 \\
\hline Within Groups & 9.144 & 48 & .190 & & \\
\hline Total & 10.674 & 50 & & & \\
\hline
\end{tabular}


From the analysis of variance it is clear that the $\mathrm{p}$ value is 0.024 which is less than 0.05 alpha level. It means that the difference in mean is not caused by sampling alone and there is a significant association between experience and QWL. Hence, null hypothesis is rejected and the data supports alternative hypothesis; which is, there is a significant relationship between experience and perceived QWL.

\section{Income vs QWL:-}

Analysis of Variance (ANOVA) test has been performed to test the associations between Income and perceived QWL. Following hypotheses are proposed prior to test:

$\mathbf{H}_{\mathbf{0}}$ : There is no significant relationship between Income and perceived QWL

$\mathbf{H}_{1}$ : There is a significant relationship between Income and perceived QWL

Table 4.4.4:- ANOVA test for Income vs QWL. (Source: SPSS Output)

\begin{tabular}{|l|l|l|l|l|l|}
\hline & Sum of Squares & df & Mean Square & F & Sig. \\
\hline Between Groups & 4.647 & 3 & 1.549 & 12.077 & .000 \\
\hline Within Groups & 6.028 & 47 & .128 & & \\
\hline Total & 10.674 & 50 & & & \\
\hline
\end{tabular}

The test reveals the $\mathrm{p}$ value of 0.000 which is highly significant at significance level 0.05 . Therefore, null hypothesis is rejected and the data supports alternative hypothesis that there is a significant relationship between income and perceived QWL.

\section{Correlation Analysis:-}

Correlation analysis was performed to see how strongly the perception on aspects of QWL relate with the overall perception of QWL (overall satisfaction). Pearson Correlation was used for the bivariate correlational analysis. Correlations are listed in table 4.5.1. All correlations are positive and are highly significant at 0.01 level (2-tailed). The correlation analysis shows that dimension 'compensation and rewards' is highly correlated towards perceived QWL whereas, 'work occupancy' and 'workplace relationship' are less correlated with perceived QWL.

Table 4.5.1:- Correlation between aspects of QWL and Perceived QWL.

(Source: SPSS Output)

\begin{tabular}{|c|c|c|}
\hline Rank & Variable & Correlation \\
\hline 1 & COMPENSATION REWARDS & 0.788 \\
\hline 2 & INVOLVEMENT IN DECISION MAKING & 0.756 \\
\hline 3 & TRAINING \& DEVELOPMENT & 0.749 \\
\hline 4 & GROWTH OPPORTUNITIES & 0.747 \\
\hline 5 & AUTONOMY & 0.731 \\
\hline 6 & CONSTITUTIONALISM & 0.697 \\
\hline 7 & WDEQUACY OF RESOURCES & 0.556 \\
\hline 8 & WORKING CONDITION & 0.502 \\
\hline 9 & WORKPLACE RELATIONSHIP & 0.501 \\
\hline 10 & & 0.501 \\
\hline
\end{tabular}




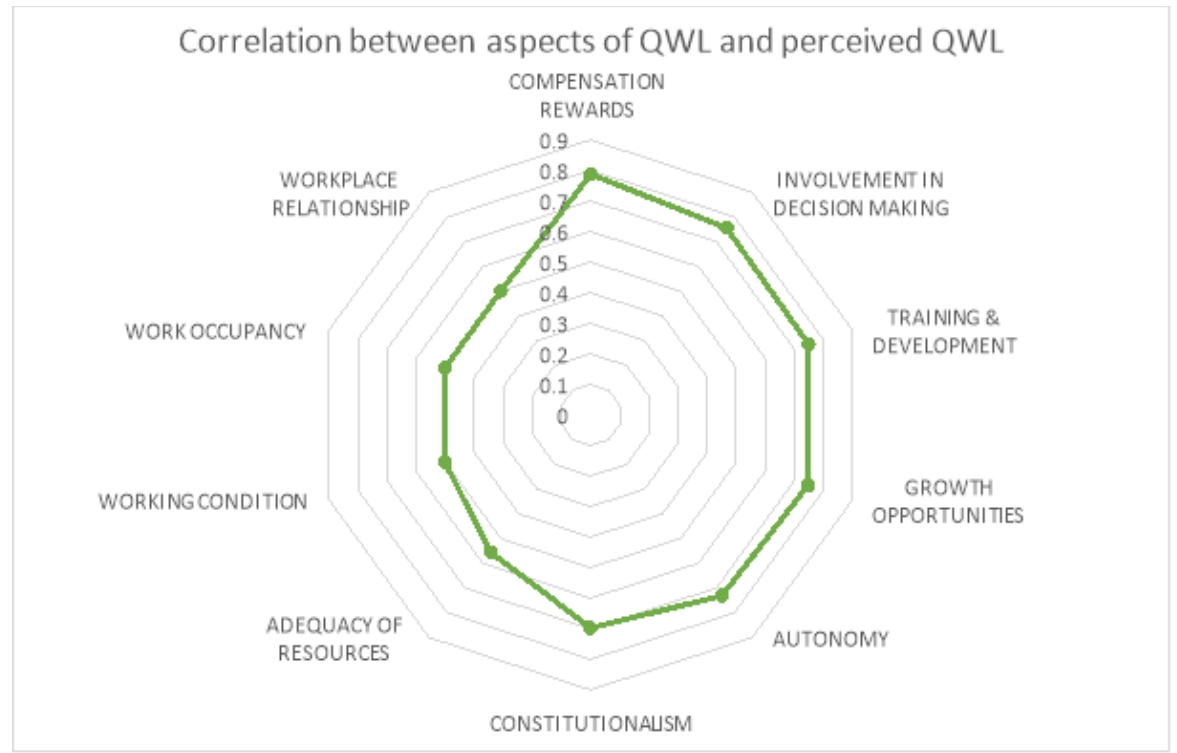

Figure 4.5.1:- Correlation between aspects of QWL and perceived QWL.

(Source: Primary Data Analysis)

\section{Summary and Conclusions:- \\ Summary of Findings:-}

* Large number of workers (almost 65\% respondents) in young age group of 18-30 years are unsatisfied with their work environment and they also have the lowest mean rating amongst all age groups.

* Large number of workers with lower earnings are seen to be perceiving their work environment as unsatisfactory. Analysis also reveals that workers in higher salary group have rated their work environment more satisfactory than those in lower salary group.

* Workers are highly satisfied with the adequacy of resources at workplace. They also rate relationship at workplace and working condition highly. Workers are unsatisfied with growth opportunities, training \& development and autonomy at work. Autonomy at work is perceived to be most unsatisfactory factor amongst all by the workers.

* Worker's perception on QWL is not affected by or not associated with gender but is associated with age, experience and income of the worker.

* Compensation and rewards, involvement in decision making, training and development, growth opportunities, autonomy and constitutionalism are highly correlated with the perceived QWL. Whereas, adequacy of resources, work occupancy, working condition and workplace relationship are less correlated with perceived QWL.

\section{Conclusions and recommendations:-}

Textile sector is one of the major pillars of Indian economy with large potential of growth. It is also a labour intensive industry providing employment to millions. Focus on quality of work life has become essential in textile industry due to increased competition creating the need of attracting and retaining skilled employees. This study has assessed the quality of work life at a textile firm named Javi Home Private Limited with the aim of gathering knowledge on perceived QWL and identifying areas of improvement. The analysis of data collected from the organization has revealed that young workers are more dissatisfied with their work environment than any other age groups. Compensation plays a great role in deciding level of satisfaction of workers. Age and experience also have an impact on how workers perceive the work environment. Workers are dissatisfied with the level of freedom they have at work, growth opportunities in organization and training programs.

It is recommended that following measures are initiated to better the status of quality of work life in a textile production firm: revamping compensation policy, creating autonomous groups for work, providing on the job training, implementing appraisal system that promotes growth, being open to ideas from young workers, and developing a sense of shared vision for inducing commitment. 


\section{Bibliography:-}

1. Anand, V. (2013). Quality of Work Life Among Employees in Indian Textile Industry - A Pragmatic Approach. Global Journal For Research Analysis, Vol 2, Issue - 5. Retrieved from http://www.theglobaljournals.com

2. Bhatia, S., \& Valecha, G. (1981). A review of research findings on abseentism. Indian Journal of Industrial Relations.

3. Gayathiri, R., \& Ramakrishnan, L. (2013). Quality of work Life- Linkage With Job Satisfaction and Performance. International Journal of Business Management Invention, Vol 2, Issue 1, 1-8.

4. India Brand Equity Foundation. (2015). Textile Industry In India. Retrieved July 5, 2015, from IBEF.ORG: http://www.ibef.org/industry/textiles.aspx

5. Indrani, G., \& Devi, S. (2014). A Literature Review on Quality of Work Life. Indian Journal of Applied Research, 101-104.

6. Indumathy, R., \& Kamalara, J. S. (2012). A STUDY ON QUALITY OF WORK LIFE AMONG WORKERS WITH SPECIAL REFERENCE TO TEXTILE INDUSTRY IN TIRUPUR DISTRICT - A TEXTILE HUB. ZENITH International Journal of Multidisciplinary Research, Vol 2, Issue 4, 265-281.

7. Jayakumar, A., \& Kalaiselvi, K. (2012). Quality of Work Life - An Overview. IRJC International Journal of Marketing, Financial Services \& Management Research, Vol 1, Issue 10, 140-151.

8. Jeyaratham, M., \& Malarvizhi, V. (2011). Quality of Work Life Among Sugar Mill Employees - A Study in Tamilnadu. ZENITH International Journal of Business Economics \& Management Research, Vol 1 Issue 3, 8996.

9. Jothi, R., \& Johnmanohar, S. (2010). Relationship between Quality of Work Life and Job Satisfaction Of Workers In Textile Industry. Summer Internship Society, Volume II, Issue - 1, 141-144.

10. Kanten, S., \& Sadullah, O. (2012). An empirical research on relationship quality of work life and work engagement. Procedia - Social and Behavioral Sciences, 360-366.

11. Kavoussi, N. (1978). The effects of unsatisfactory working condition on the Epidemology of Unauthorised abseentism in an old textile factory. Journal of Human Ecology, 81-87.

12. Mary, S. (2012). The Quality of Work Life in Textile Industry. International Journal of Physical and Social Sciences, 294-305.

13. Muthukumar, E., Alex, R., \& Vidhya, S. (2014). A CRITICAL ANALYSIS OF QUALITY OF WORK LIFE PRACTICES AT SALEM STEEL PLANT AND JSW STEEL LIMITED, TAMIL NADU. International Journal of Business and Administration Research Review, Vol.2, Issue.3, 92-99.

14. Nanjundeswaraswamy, T. S., \& R, S. D. (2013). Quality of Work Life of Employees in Private Technical Institutions. International Journal of Quality Research , 431-441.

15. Nanjundeswaraswamy, T. S., \& Swamy, D. R. (2012). A LITERATURE REVIEW ON QUALITY OF WORK LIFE AND LEADERSHIPSTYLES. International Journal of Engineering Research and Applications (IJERA), 1053-1059.

16. Raghvan, S. (1978). Workers participation in BHEL: 1. Vikalpa 3(3).

17. Rathmani, P., \& Rameshwari, R. (2013). A Study on Quality of Work Life of Employees in Textile IndustrySipcot,Perundurai. Journal of Business and Management (IOSR-JBM), Vol 8, Issue 3, 54-59.

18. Sharma, N., \& Verma, D. S. (2013). Importance of Quality of Work Life in Small Scale Industries for Employees. MNK Publication, International Journal of Latest Research in Science and Technology, Vol 2, Issue 2, 495-499.

19. Shiney, C. (2012). Quality of Work Life and Organisational Performance Parameters at Workplace. SEGi Review, 36-47.

20. Singh, J. (1983). Experiments in India: Trials and Triumphs. Abhigyan (Fall).

21. Subhashini, S., \& Gopal, R. (2013). QUALITY OF WORK LIFE AMONG WOMEN EMPLOYEES WORKING IN GARMENT FACTORIES IN COIMBATORE DISTRICT. Asia Pacific Journal of Research, Vol 1, Issue XII, 22-29.

22. Subrahmanian, M., \& Anjani, N. (2010). Constructs of Quality of Work Life- A Perspective of Textile and Engineering Employees. Asian Journal of Management Research, 299-307.

23. Valarmathi, A., \& Hema, B. (2013). A Study on Quality of Work Life In Textile Sector in and Around Coimbatore District. Journal of Business Management \& Social Sciences Research (Vol. 2), 42-46.

24. Yadav, R., \& Ashu, K. (2014). Literature Review on Quality of Work Life and Their Dimensions. IOSR Journal Of Humanities And Social Science (IOSR-JHSS), Vol 19, Issue - 9, Ver. 5, 71-80. Retrieved from http://www.iosjournals.org. 